\title{
PSYCHOLOGICAL ASPECTS OF ANDRONGO SUPPORT
}

\section{Maslianikova I. V.}

\section{INTRODUCTION}

At the present stage, the adult education is actively developing and is mobile. It has consistently expanded its influence on various social and professional systems. After all, the assimilation of a new social experience by an adult is conditioned by the their activity, specific needs and personal interest. The adult is a unique holistic system that strives for selfactualization. However, it should be borne in mind that usually an adult is very cautious about himself as a student. An adult prefers such an organization of the educational process in which other people will need her experience. In addition, age-related psychophysiological changes, personality traits that have become more acute with age, and psychological barriers that can be caused by a variety of reasons hinder the acquisition of new knowledge and practical skills. All this can negatively affect both the procedural and the effective side of the adult learning process. Thus, having a certain experience and subjective position in education, an adult knows why she is learning and how he will be able to use the knowledge, skills and abilities in his personal and professional life. Therefore, the quality and practical orientation of educational services comes to the fore for an adult. Therefore, for maximum efficiency of the educational process should be included in the organization of psychological support. Psychological support has a positive impact on the prevention of difficulties during learning and solutions problems that have already arisen and interfere with the successful implementation of the educational process of adults.

\section{The concept of support in modern psychological and pedagogical science}

Actualization of scientific approaches to psychological support aims to reveal the basic semantic units, to analyze the diversity of movement and focus, to consider different types, indicators and criteria. 
Etymologically, the concept of support is close in value to the promotion, the total movement by one person to another to overcome difficulties.

"To accompany, as indicated in the "Explanatory dictionary of the Russian language" edited by D.N. Ushakov, means to go, to go with someone as a companion or guide" . In the dictionary V.I. Dal support is interpreted as an action on the verb "to accompany", that is, "to go along with the purpose, to conduct, follow"2. If we turn to the common understanding of the word support, it means the meeting of two people and the joint passage of a common segment of the pathway, and to accompanymeans to pass with someone part of his pathway. In an escort situation, there are three main components: the one who is accompanied; the one who accompanies; and the path they travel together. We can say that we are talking about the joint existence of people in a certain period of human life. Accompanying (satellite) appears as a person, protects and helps the traveler on the road to cope with the variability of the path.

The concept of "support" V. Slyusarev used to refer not prescriptive forms of psychological assistance aimed "not merely to enhance or improve, and to development and self-development of consciousness of the person", the help that triggers the mechanisms of self-development and activates its own human resources ${ }^{3}$. Many researchers note that support "involves the maintenance of naturally developed reactions, processes of personality". Moreover, successfully organized psychological support opens up prospects for personal growth, helps a person to enter the "zone of development", which is not yet available to him.

The analysis of other interpretations of psychological support in the studies of various authors showed their content:

$\checkmark$ psychological support as a system of professional activity of a psychologist aimed at understanding the socio-psychological conditions for successful learning and psychological development of the child in situations of school interaction (M. R. Bityanova);

$\checkmark$ psychological support as a multidisciplinary method which ensures the unity of the efforts of teachers, psychologists, social and medical workers, and consists in the formation of the orientation field of

\footnotetext{
${ }^{1}$ Ушаков Д.Н. Толковый словарь русского языка. М.: ООО «Издательство АСТ», 2008. 1054 с.

2 Даль В.І. Толковый словарь русского языка. Современное написание. М.: АСТ, 2010. 815 с.

${ }^{3}$ Слюсарев Ю.В. Психологическое сопровождение как фактор активизации саморазвития личности: Автореф. дис. ... канд. психол. наук: 19.00.01; Санкт-Петербург. гос. ун-т. С.Пб., 1992. 16 с.
} 
development, where responsibility for the activity shall be the subject of development (E. I. Kazakova);

$\checkmark$ psychological support as the position of the psychologist in relation to the subjects of interaction where the main principles are inclusion, participation, welfare (T.N. Chirkova).

In recent years, the paradigm of support in modern psychological science is becoming particularly popular. Many authors recognize the existence of the specifics of the implementation of psychological support in different types of educational institutions, due to different approaches to educational challenges, opportunities and objectives, other characteristics specific to educational environments (M. R. Bityanova, T. Zemskaya, E.A. Kozyrev, V.E. Phelan, T.I. Mote, V. Rodionova, M. Stepnicka etc.). The authors consider the accompanying activity of each specialist from the standpoint of creating conditions for ensuring the educational process in accordance with the individual capabilities of each participant of educational activities, the development of his personality. A number of principles that include regulates psychological support how the interaction of the accompanying person is organized:

$\checkmark$ the priority of interests accompanied,

$\checkmark$ the continuity, multidisciplinary approach,

$\checkmark$ formation of a unified attitude to the participant of educational activities on the part of all participants of support,

$\checkmark$ constant information exchange between them with a clear understanding of their part of the activities and lines of interaction.

According to the direction of work psychological and pedagogical support includes different approaches:

The first is support-cooperation, which envisages joint planning specialist performs a support and participant in the educational activities, analysis, creativity, reflection requires the actions required for the following self-overcoming of the problems that have arisen, that is, to exercise personal responsibility, creativity, unique qualities of the participant of educational activity.

The Second is support-initiation, known since the time of Socrates, the essence of which was perfectly formulated by M. Montessori: "Help me to do it myself, doing nothing for me, direct in the right direction, push to a decision, and I will do everything else myself". Organizing support-initiation, the participant of support creates the conditions for 
free, individual, independent choice of ways and means of solving educational problems for the participant of educational targets. Thus, the participants of educational activities realize their personal creative potential and at the same time enrich, develop, while maintaining its individual originality.

The third is support-warning, when the specificity of age, limited individual experience of the participant of educational activity acquires special importance. Ahead of undesirable events, predicting their possible adverse development, participant support in the framework of supportprevention involves missteps party educational activity and, thereby, helps to choose appropriate solutions, taking into account the problematic educational situation. Support-warning becomes useful and valuable if its content and form, unobtrusive and delicate, modern, psychologically and pedagogically competent, targeted, measured, and most importantly, if accompanied by a warning in all cases fully meets its developmental and remedial purpose, working for the future ${ }^{4}$.

Analysis of the literature showed that psychological and pedagogical support still does not have a complete holistic scientific description, there are signs that relate to various branches of scientific knowledge: pedagogy, social pedagogy, psychology, sociology. It is identified with the methods and forms of education, such a position of participants of educational activities and support of participants as "free communication", "comradeship" "inner mood" (N. Krylova).

Scientific sources indicate that today there are a number of reasons for the classification of types of psychological support, including the form of work, focus, subject and object of psychological support. Analysis of the psychological literature (G. Bardier, M. R. Bityanova, Ivan Romazan, T. Cherednikov, T.I. Chirkova, etc.) have shown that party support needs allocation of parameters for assessing the effectiveness of its system. So, Y.P. Fedorov, analyzing allocation problems performance criteria of the model of psychological support, concluded that they presented two groups of indicators: from the specialist, and the learning environment. At the same time, the author points to the fuzziness of the criteria, which complicate their practical application, their further specification, the

\footnotetext{
${ }^{4}$ Психолого-педагогічний супровід і підтримка в умовах модернізації освітньо-виховного простору: [Електронний ресурс] // Режим доступу: URL:http://osvita.ua/school/upbring/1334
} 
implementation of which is possible due to the allocation of normative guidelines of each age ${ }^{5}$.

In General, psychological support is a concept quite common in working with different categories of persons, and actually this type of psychological activity should be distinguished from other types of assistance in difficult situations, such as: medical rehabilitation, psychological and pedagogical rehabilitation, social rehabilitation, psychological rehabilitation, psychological correction, psychological therapy, psychological counseling, psychological prevention, psychological support, psychological adaptation.

Analysis of the psychological literature suggests that today support is a special form of prolonged social and psychological assistance. Unlike the correction it suggests is not "corrective and restructuring", and search for hidden resources of human development, reliance on their own capabilities and on establishing psychological conditions for restoring ties with the human world. In our opinion, the ideas of psychological support to the greatest extent correspond to the progressive ideas of national psychology, pedagogy and social work. In each case, the tasks of support are determined by the characteristics of the person who is provided with psychological assistance, and the situation in which the support is carried out. An essential characteristic of psychological support is the creation of conditions for the transition of the individual to self-help. Conventionally, we can say that in the process of psychological support specialist creates the conditions and provides the necessary and sufficient (but in any case not excessive) support for the transition from the position of "I can not" to the position of "I can cope with their life difficulties".

\section{Psychological foundations of adult education}

In adult education, from a psychological point of view, a high degree of freedom and choice of all parameters of the educational process (goals, motives, forms, methods, and control) is realized. In this case, the teacher plays the role of a mentor, a consultant, helping an adult who is learning. It is the recognition of the leading role of an adult student that was taken by teachers and psychologists as the basis for understanding the specifics of adult education. Adult education involves the rational distribution of

\footnotetext{
5 Федорова Ю.П. Психологическое сопровождение личностного развития младших школьников в частной школе: Автореф. дис... канд. психол. наук: 19.00.07; Вятский государственный гуманитарный университет. Курск, 2003. 18 с.
} 
periods of study and work of a person throughout her life, the acquisition of the necessary knowledge, skills, qualities, personal orientations as the need for them.

So, the psychological foundations of adult education are as follows:

$\checkmark$ an adult who learns has a leading role in the learning process;

$\checkmark$ an adult student seeks self-realization and independence;

$\checkmark$ an adult student already has life (social, professional, personal) experience that can be used as an important source of learning both to him and his colleagues;

$\checkmark$ an adult learns to solve an important life problem and achieve a specific goal;

$\checkmark$ an adult learner expects an urgent received during the training of knowledge, skills and qualities;

$\checkmark$ adult learning activity is largely due to temporary, social, professional factors limiting or contributing to the learning process;

$\checkmark$ adult learning process is organized as a joint activity of the student and the teacher at all stages: planning, implementation, evaluation and, to a certain extent, correction ${ }^{6}$.

On this basis, in adult education, the leading role in the organization of the learning process at all stages belongs to the adult, since he is an equal subject of the learning process.

The adult student takes an active part in the preparation and implementation of the training program and at the same time carries out joint activities with the teacher. Defining in this process is the interaction between the teacher and the adult student.

The main purpose of adult education is to develop critical and creative thinking. In this regard, the key provisions can be formulated in this way:

$\checkmark$ an adult is a social being who thinks critically and is capable of learning;

$\checkmark$ critical and creative types of thinking are the most acceptable and contribute to adult development;

$\checkmark$ the combination of collective learning and self-learning fully contributes to the development of critical and creative thinking;

\footnotetext{
${ }^{6}$ Професійне навчання дорослого населення: теоретико-методологічні засади: [монографія] / авт. кол.: Ничкало Н.Г., Радкевич В.О., Щербак О.І., Дорошенко Н.І., Василенко О.В., Скульська В.С. Кіровоград: Імекс-ЛТД, 2013. С. 50-63.
} 
$\checkmark$ adult education is not aimed at the transfer of ready-made knowledge, but at their selection, synthesis and open dialogue between adult students and teachers.

Given the above, the characteristics of adult education are:

$\checkmark$ non-prescriptive nature of training;

$\checkmark$ problem-setting and acquisition of necessary knowledge;

$\checkmark$ orientation training on results in solving problems;

$\checkmark$ communication with practice and verification of learning outcomes;

$\checkmark$ constant discussion of the content, forms and methods of training in the study group;

$\checkmark$ taking responsibility for the learning process by all group members and the teacher; members ${ }^{7}$.

$\checkmark$ learning outcomes assessment process involving all group

Accordingly, adult students should be able to listen to each other, respect each other's opinions and feelings, critically perceive the thoughts expressed, ask correct questions and seek to share the opinion of the other. Dialogue assumes equality between the members of the study group, frankness, gullibility, respect each other, mutual respect, integration of thinking and learning when the adult learner is in control of their thinking and learning, unlike learning situation in which the individual mind just adapts to the authority or the experience of others.

After all, from the point of view of andragogy, learning adults have a deep need for independence, self-government, a leading role in the learning process. The task of the teacher is to encourage and support the development of the adult learner. The main characteristic of the educational process is an independent definition of adult learner parameters of learning, knowledge acquisition, formation of skills, skills, necessary qualities. In this case, an adult to the extent of his growth accumulates his own experience, which can be used as a source of learning. Accordingly, the main forms of learning are experiments, discussions, solving specific problems.

The readiness of adult students to learn is determined by their need to acquire knowledge, skills and qualities to solve specific life problems. In this case, the task of the teacher is to provide students with the necessary

\footnotetext{
${ }^{7}$ Професійне навчання дорослого населення: теоретико-методологічні засади: [монографія] / авт. кол.: Ничкало Н.Г., Радкевич В.О., Щербак О.І., Дорошенко Н.І., Василенко О.В., Скульська В.Є. Кіровоград: Імекс-ЛТД, 2013. С. 50-63.
} 
methods and criteria, to help them in the selection of the necessary knowledge, skills and qualities. In this regard, the educational process is based on the individualization of learning and joint activities of the teacher and adult students.

However, it should be borne in mind that with age, it becomes more difficult for a person to be involved in educational processes through certain internal barriers (Fig. 1).

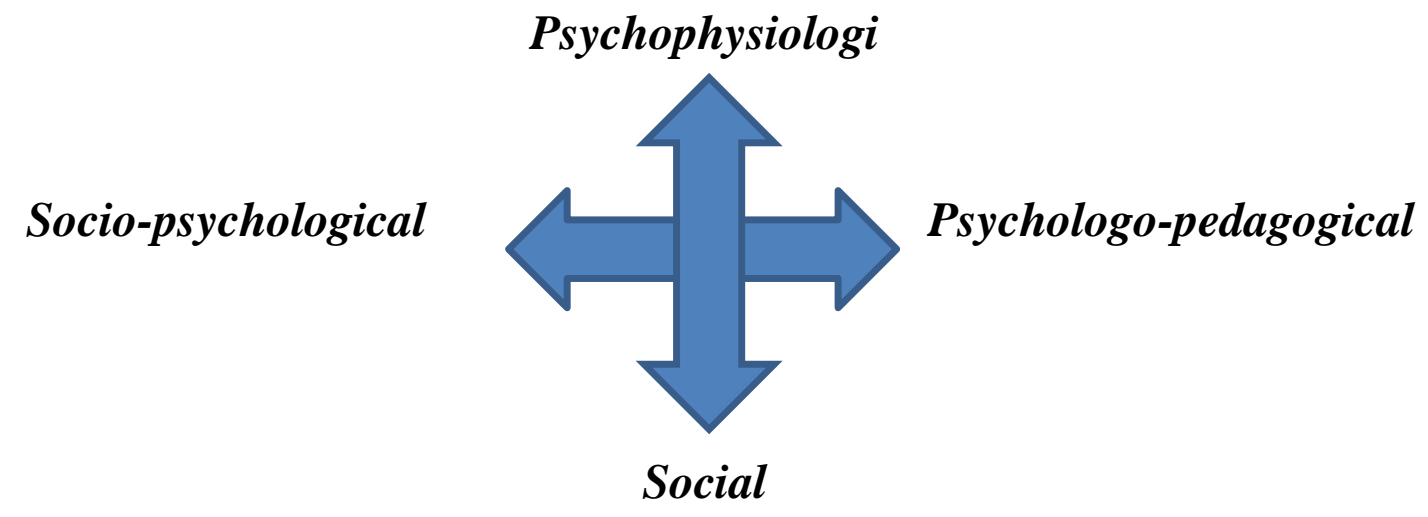

\section{Fig. 1. Internal barriers to the inclusion of adults in educational processes}

The essence of internal barriers is as follows:

1. Psychophysiologic. Some adults have an internal barrier to their ability to learn. This barrier is to some extent based on the myth of the decline with age of the ability to perceive, remember, reproduce educational information. However, scientists have proved that it is possible to study successfully at any age, but in different periods of life, different memory functions, types of attention come to the fore, motivation changes, but in General, an adult is always able to acquire appropriate individual ways of optimal work with information. However, the motivation to learn must be sustainable.

2. Socio-psychological. Some adults are uncomfortable in the position of a student. This is especially true for those who hold administrative positions. Psychologically, they are not ready to become an "object" of pedagogical influence.

3. Social. Increased requirements for a new level of education on the part of society lead to the fact that the continuation of education by an adult is impractical. 
4. Psychological-pedagogical. Installation aborted in the adult, the need for education throughout life. The lack of awareness about own abilities, peculiarities of perception and assimilation of educational material, information needs can hinder the continuity of education. After all, a person may simply not be aware of the forms of adult education ${ }^{8}$.

In this regard, there is an extremely important need for psychological support during adult education.

\section{The essence of psycho-androngo support}

Speaking about psychological support of adults, it seems to us fundamentally important to clarify the terminological apparatus, which will be used in this context. Consider how the term "support" is interpreted in the scientific psychological and pedagogical literature.

Thus, from the standpoint of a systematic approach, in which human development is understood as the choice of ways to solve a problem situation and the development of the subject of certain innovations, support acts as a special assistance to the subject, aimed at preventing and overcoming the problems of its development. Support in this situation is aimed at revealing the inner potential of the individual.

Kazakova E.I. defines maintenance as a method that provides conditions for the subject of development to make optimal decisions on various situations of life choice (ie, many problematic situations) ${ }^{9}$.

Some researchers (L.S. Alekseeva, I.V. Romazan, T.S. Cherednikova, etc.) note that support involves the support of mental development of the individual, including opens up prospects for personal growth ${ }^{10}$.

Based on the provisions of the personality-oriented approach, Zeer E.F. interprets psychological support as a holistic process of study, formation, development and correction of professional formation of the individual. At the same time, the accompanied person is not provided with ready-made recipes for solving his problems, but takes measures that set him up to perform the necessary actions in this situation, to make the best decision for him.

\footnotetext{
${ }^{8}$ Сучасні технології освіти дорослих: посіб. / авт. кол.: Л.Б. Лук'янова, О.В. Аніщенко, Л.Є. Сігаєва, С.В. Зінченко, О.В. Баніт, Н.І. Дорошенко. - Кіровоград: Імекс-ЛТД, 2013. С. 105-118.

9 Бизяева А.А. Психология думающего учителя. Педагогическая рефлексия. Изд-во: ПГПИ им. С.М. Кирова, 2004. 216 с.

${ }_{10}$ Адольф В.А., Ильина Н.Ф. Инновационная деятельность педагога в процессе его профессионального становления / Агентство образования адм. Краснояр. края, Краснояр. краев. ин-т повышения квалификации и проф. переподгот. работников образования. Красноярск: Поликом, 2007. $190 \mathrm{c}$.
} 
According to Slusarev Y.V., under the accompaniment is understood as a specially organized process, aimed at creating a "transitional space" a safe environment in which it becomes possible the exit of the individual from alienation (from themselves, other people, activities, the world at large), the reconstruction of its subjective image of the world and reconnect with themselves, others, activities ${ }^{11}$.

Vasilkova T. A. the main purpose of psycho-androge support, put forward "to maintain an optimal level of activity as a psychological basis of professional and social mobility", which should ensure the inclusion of people in the educational activity taking into account its psychological potential ${ }^{12}$.

After analyzing all of the above and taking into account the specificity of theory and methods of adult learning, we propose to consider psychological support adult learning as a system of measures organized by tutor in virtual or real educational environment aimed at creating favorable conditions to prevent possible difficulties or overcome those that have arisen, to stimulate private resources adult student to individual educational search.

We believe that in the educational activities of adult students psychological support should be carried out at the group and individual levels, and consists in the organization:

1. increase of educational and professional motivation;

2. increased mental and physical activity;

3. productive communication with all subjects of training (colleagues, tutor/coach/teacher);

4. forecasting, planning, analysis, self-reflection, self-assessment of own educational activities;

5. realization of personal and creative potential during training;

6. getting rid of negative emotions, fatigue, creating a positive emotional atmosphere.

The organization of educational activities of adults does not provide a person who is authorized to provide psychological support to students, based on the above understanding. However, not providing psychological

\footnotetext{
11 Адольф В.А., Ильина Н.Ф. Инновационная деятельность педагога в процессе его профессионального становления / Агентство образования адм. Краснояр. края, Краснояр. краев. ин-т повышения квалификации и проф. переподгот. работников образования. Красноярск: Поликом, 2007. $190 \mathrm{c}$.

12 Василькова Т.А. Основы андрагогики: учебное пособие. М.: КНОРУС. 2009. 256 с.
} 
support to adult students significantly affects the quality of educational services and the learning process itself. Ignoring the needs of participants in educational activities leads to all sorts of misunderstandings, psychological stress, reduces motivation to learn, creates conflict situations and the like. Therefore, if there is a demand for psychological support provides tutor, coach or teacher during training sessions and outside them.

\section{The implementation of psycho-adragon support in practice}

Let us proceed to the consideration of the above outlined components of psychological support of adult students in practice.

Motivation is responsible for the direction of educational activities, the intensity and duration of preservation of its basic parameters. It is formed in connection with the development of worldview, General, individual and special abilities and awareness of the individual's place in life. Motivation is complex, contradictory and variable.

There are various motivational conditions: interests, desires, aspirations, intentions, passions, attitudes (semantic, target, operational). By making a purposeful impact on the motivational state of the individual, you can influence the motivation to learn and develop.

Thus, the psychological problems of adult students, which can negatively affect the learning motivation, are manifested in fear of taking responsibility for learning, unwillingness to change the usual stable position, doubt of their abilities, fear of showing incompetence, inability to learn or be worse than others. Exercises aimed at presenting oneself as a professional in a certain field of knowledge will help to stabilize one's own professional abilities. Exercise "My childhood dream" is recommended for the beginning of training sessions, in order to meet the group members. Its implementation is that everyone writes on a piece of paper who he wanted to be as a child (actress, doctor, teacher, astronaut, etc.). Tutor (coach, teacher) collects all the records in the hat. Next, participants take turns not looking to get someone's childhood dream and voice it. All together try to slap this person and then listen to a short story of the owner of this dreamwhy it was wanted to become this specialist, for example, a doctor, what he liked in this profession, a person eventually chose this profession. Another exercise "Provocateur-professional" can be carried out within training meetings, when participants already have an idea about each other and can not only present their profession, but also to defend their professional 
opportunities. The participants split into dev groups: some of them are provocateurs, and other professionals. The task of "professionals" is to tell about their professional activities in 3 minutes. Forth the next 3 minutes "provocateurs" ask such questions: 1. Why do you do it? 2. Why do you do it this way? Questions are asked several times to hear reasoned answers about the motives of their own professional activities, especially its implementation, professional opportunities and the like. The exercise is useful for both groups of participants and contributes to the stabilization of professional motivation, awareness of their own professional experience, develops interest in learning.

One of the most difficult problems in adults in the transition from professional to educational activities, the problem of re-motivation - with motivation to work motivation to study. At the stage of transition from professional activity to educational one should pay the greatest attention. Since most of the learning skills in adulthood are lost, a special adaptation period is needed for the restructuring of psychological subsystems for a new activity. Taking into account the peculiarities of adult education, adaptation should be managed, special and intensive. A means of adaptation can be a clarifying professional orientation in the framework of training. Here, the appropriate to get acquainted with professiograme future activities, qualification requirements, future growth, typical working conditions, with the demand for a new profession in the labour market etc.

With age as a negative phenomenon, scientists note that the processes of perception, memory, thinking in an adult are not as productive as in a child or teenager. In this regard, of paramount importance are the methods, techniques and methods of training, contributing to both the increase in mental and physical activity, as well as to maintain their optimal level for learning. To this end, the tutor (coach, teacher) should be used at the beginning of classes, as well as in the middle of training exercises aimed at increasing brain activity, synchronization of hemispheres, improving mental activity, improving memory and attention, facilitating the process of reading and writing. These can be the following exercises. Exercise "Ears" is aimed at energizing the brain. Its execution is to straighten and stretch the outer edge of each ear with the same hand in the direction up and out from the top to the ear lobe (five times) and massage the ear. Exercise "Flashlights" aims to promote interhemispheric interaction, arbitrariness and self-control of mental functions. Its implementation 
involves the following sequence of actions: put hands on the table; one balled in a fist, the other lies on the table with his palm; at the same time change the position of the hand (if right fist and left hand palm, then change to the right - hand, left - fist, and so on). Another of the effective exercises on this list is called "Fist- edge-palm".
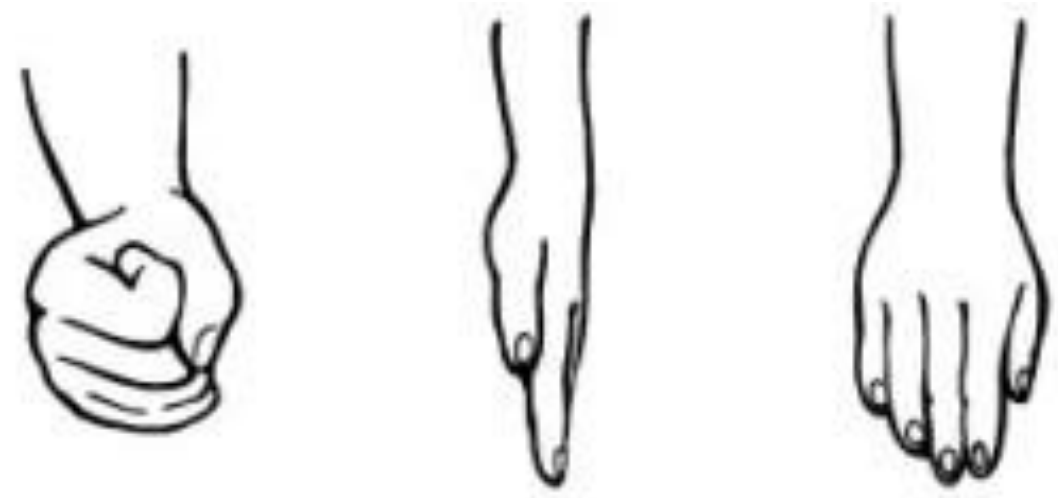

Fig. 2. Hand position during exercise "Fist- edge-palm"

Tutor (trainer) shows participants three-position palm on the table, consistently replacing each other: the open palm on the table, hand clenched, the palm squarely on the table. First, the exercise is performed together with the tutor, then independently:

1) right hand palm;

2) left hand palm;

3) with both hands at the same time.

It is important to change the pace of execution, then accelerating, then slowing it down.

Speaking about the psychological features of mental activity of an adult student, it should also be emphasized that with age, different functions become more interconnected, coordinated, integrated into a single whole, which allows a person to compensate for the shortcomings in the development of one function (for example, memory) due to the higher development of another (for example, thinking). For this purpose, when teaching adult students it is appropriate to use such teaching methods as: analysis of problem and practical situations, brainstorming, association method, business games, group discussions and others.

Organization of interaction and effective communication is the next point of adult education, which requires psychological support. Due to 
different circumstances, the communication skills of adult students who find themselves in the same learning space may be different. Not everyone equally aptly manages to formulate their own opinion, give feedback or even raise a question. Tutor (coach, teacher) should direct their efforts to ensure that the essence of the dialogue between adult students was to recognize the uniqueness of each other by each partner, their mutual equality in relation to each other, differences and originality of perspective, the orientation of each to the understanding and active interpretation of his perspective partner, waiting for the answer and its glorification in its own expression and mutual enrichment of the dialogue partners. The beginning of such interaction can be exercises aimed at training the speech apparatus, for example, with the help of pronouncing all of us known tongue twisters.

Also accurate can be exercises to explore, such as "Snowball of name", which is to be called by one word and his name one letter (dark Dmitry) continue to pass the torch, where the next party is already talking of the previous phrase and its etc. Along with this, you can use exercises that contribute to the ability to listen and respect for the interlocutor.

This can be an exercise "Communication options". Participants are divided into pairs and take turns using the following communication options: synchronous conversation, ignoring, back-to-back, active listening. Time use every option communication-30 sec. The topic of conversation can be any, the main thing to make it clear to the participants how important it is to be able to listen and respect the communication partner.

Speaking about the psychological support of adult learning, forecasting, planning, analysis, self-reflection and self-evaluation of their own learning activities, also requires special attention. First of all, the importance of the organizational aspects of learning process such as: creating a shared email address, social network, exchange contacts, selection of the responsible person in the group, and the like, to facilitate the timely transfer of information.

The tutor (coach, teacher) should pay attention to the clear articulation of educational tasks and requirements for their implementation, to give clear criteria for assessing educational achievements available to all participants in the educational process. Obligatory moment for adult students have the opportunity not only to keep records in notebooks, but also photo and video surveillance, the use of a dictaphone in order to better 
assimilate educational information. In addition, in the context of the above, it is useful to use the method of working groups in the classroom of adult students, where it is possible to predict, plan and evaluate educational achievements. It is also important to recommend the tutor (coach, teacher) to evaluate the educational results of other participants and their own achievements and to argue your answer based on the criteria: completeness, correctness, originality and the like.

Very important during the educational activities of adult students is the realization of their personal and creative potential. Adult students have a lot of experience-professional, personal, domestic. With this in mind, learning tasks should be designed to take into account the well-known David Kolb learning model, which is based on the gradual formation of mental actions. This theory involves a learning cycle that consists of 4 different stages and 4 different learning styles:

1) experience is the property of the new or a new interpretation of the old;

2) analysis/reflection - comprehension of experience;

3) theory - formation of theoretical models;

4) practice - active experimentation, the use of new experience.

At the same time, it will be appropriate to use the tutor (coach, teacher) during the training method of creative projects (individual or group), when adult students have the opportunity to construct their own ideas, originally issue them taking into account the creative approach and technical capabilities and voice them, in order to receive feedback from their colleagues.

The emotional component of the educational process is of particular importance, including when it comes to adult students. Given the conditions of the present, adults are constantly under the influence of stress factors, are in conflict situations, often experiencing fatigue, negative emotions, which leads to emotional exhaustion. Being in the classroom for an adult is not quite a standard situation, so emotional stress can not be avoided. To this end, it is advisable to carry out exercises aimed at relaxing and getting rid of negative emotions.

Among the list of such exercise "Algae", its implementation involves the slow movement of the plant, which pushes the water. Exercise can be done with both open and closed eyes. Lead time up to 3 minutes. The next exercise is aimed at relaxing the whole body is called "Twisting". During 
its execution, the hands are along the body, slow movements to the left and right resemble a spiral. Exercise "Annoying fly" aims to relieve tension in the muscles of the face. The participant should imagine that came annoying insect that falls directly on the nose. The task without the help of hands to drive it away. Should wrinkling nose, make as many wrinkles in your nose as you need to twist nose - up, in different sides. After relaxing one part of the face, you can move on to the next forehead, chin and others. Exercise is done to obtain a pleasant relaxing feelings. Such exercises can be used by the tutor (coach, teacher) before the start of training sessions and in between.

Further ways of improving approaches to the implementation of psychological support as a system of professional training of adults provide for further clear development of the concept of work aimed at creating the most favorable conditions for the comprehensive development and training of adults in various educational situations of micro-and macro-social interaction.

\section{CONCLUSIONS}

Summarizing the above, we can state the following. The analysis of scientific literature on this problem showed sufficient knowledge of pedagogical aspects of the theory and methodology of adult education. At the same time requires further study of the psychological aspect of adult education, namely androgynous support. In the presence of demand for this key aspect of educational activity, science has not developed a holistic view of the content, especially the implementation of psychological support of adult education and the competent person who is responsible for its qualitative implementation. Based on the practical experience of interaction with adults in the educational space, the author gave a subjective view of the psychological characteristics of the organization of androgynous support. Of course, the materials given in the article do not exhaust the whole essence of the problem of androgynous support, which indicates the need for further research in this direction.

\section{SUMMARY}

The article relates to the problems of adult education and is devoted to the issue of psychological support of adult students. Practical experience has shown that psychological support is quite an important component of 
adult education, which directly affects the quality of educational services to adult students. However, it was found that neither in the theoretical nor in the practical aspect of adult education has a holistic view of androgynous support, there is no single interpretation of this concept, and most importantly - has no clear understanding of the specialist who should implement it. The author analyzed various approaches to understanding the concept of "psychological support" and offered his own vision, which is based on the psychological characteristics of adult students. Based on practical experience in working with adult students it was pointed to the main components of psychological support of adult education. The psychological support should include: increase of educational and professional motivation; increased mental and physical activity; organization of effective communication with all subjects of training (colleagues, tutor/coach/teacher); assistance in forecasting, planning, analysis, self-reflection and self-assessment of own learning activities; assistance in realization of personal and creative potential of adult students; creating a positive emotional atmosphere during training and getting rid of negative emotions. Psychological support of adult education should occur both at the group and individual levels. It should be conducted by the appropriate specialist - teacher, coach, tutor, coach, i.e. competent person in accordance with the purpose of training. Given the above, it should be noted that the issue of psychological support of adult education continues to be quite an urgent problem that requires further study and development both in theoretical and practical terms.

\section{REFERENCES}

1. Dal' V.I. Tolkovyj slovar' russkogo yazyka. Sovremennoe napisanie. M.: AST, 2010. $815 \mathrm{~s}$.

2. Adol'f V.A., Il'ina N.F. Innovacionnaya deyatel'nost' pedagoga v processe ego professional'nogo stanovleniya. Krasnoyarsk: Polikom, 2007. $190 \mathrm{~s}$.

3. Bizyaeva A.A. Psihologiya dumayushchego uchitelya. Pedagogicheskaya refleksiya. Izd-vo: PGPI im. S.M. Kirova, 2004. 216 s.

4. Vasil'kova T.A. Osnovy andragogiki: uchebnoe posobie. M.: KNORUS. 2009. $256 \mathrm{~s}$.

5. Lipskij I.A. Social'naya pedagogika. M.: Dashkov i K., 2017. 280 s. 
6. Psihologo-pedagogichnij suprovid i pidtrimka v umovah modernizaciï osvitn'o-vihovnogo prostoru: [Elektronnij resurs] // Rezhim dostupu: URL:http://osvita.ua/school/upbring/1334

7. Profesijne navchannya doroslogo naselennya: teoretikometodologichni zasadi: [monografiya] / avt. kol.: Nichkalo N.G., Radkevich V. O., SHCHerbak O. I., Doroshenko N.I., Vasilenko O.V., Skul's'ka V. C. Kirovograd: Imeks-LTD, 2013. S.50-63.

8. Slyusarev YU.V. Psihologicheskoe soprovozhdenie kak faktor aktivizacii samorazvitiya lichnosti: Avtoref. dis. ... kand. psihol. nauk: 19.00.01; Sankt-Peterburg. gos. un-t. S.Pb., 1992. 16 s.

9. Suchasni tekhnologiï osviti doroslih: posib. / avt. kol.: L.B. Luk'yanova, O.V. Anishchenko, L.Ye. Sigaєva, S.V. Zinchenko, O.V. Banit, N. I. Doroshenko. Kirovograd: Imeks-LTD, 2013. S. 105-118.

10. Ushakov D.N. Tolkovyj slovar' russkogo yazyka. M.: OOO “Izdatel'stvo AST", 2008. 1054 s.

11. Fedorova Yu.P. Psihologicheskoe soprovozhdenie lichnostnogo razvitiya mladshih shkol'nikov $\mathrm{v}$ chastnoj shkole: Avtoref.dis... kand. psihol.nauk: 19.00.07; Vyatskij gosudarstvennyj gumanitarnyj universitet. Kursk, 2003. 18 s.

\section{Information about the authors:} Maslianikova I. V.

Candidate of Psychological Sciences, Associate Professor, Associate Professor at the Department of Psychology and Pedagogy of the Educational and Scientific Humanitarian Institute of the V. I. Vernadsky Taurida National University 33, Ivana Kydri str., Kyiv, 01042, Ukraine 